\title{
PENINGKATAN KEMAMPUAN PESERTA DIDIK DALAM PEMBELAJARAN MATERI TEKS EDITORIAL DENGAN MODEL DISCOVERY LEARNING BERORIENTASI HOTS MELALULUI GOOGLE CLASSROOM
}

\author{
EMBANG ULUK \\ SMAN 1 Malinau Kalimantan Utara \\ Email : Embanguluk2019@gmail.com
}

\begin{abstract}
ABSTRAK
Berbahasa menjadi sebuah point penting yang harus menjadi landasan bagi setiap orang untuk menjalin komunikasi dengan orang lain sehingga Bahasa Indonesia menjadi sebuah pembelajaran dasar yang diwajibkan dalam kurikulum SMA/MA/SMK. Pada materi pembelajaran teks editorial perlu menerapkan model pembelajaran tepat guna meningkatkan kualitas kemampuan dari peserta didik. Dalam hal ini pemanfaatan model discovery learning yang berorientasi hots melalui google classroom dapat meningkakan kemampuan peserta didik. Metode penelitian yang digunakan oleh peneliti adalah studi literature dimana mengumpulkan semua informasi terkait baik dari jurnal, buku, model belajar, dan dll. Hasil penelitian menunjukkan bahwa penggunaan model pembelajaran discovery learning berorientasi hots melalui google classroom sendiri dalam secara signifikan meningkatkan kemampuan belajar peserta didik. Peserta didik dapat melakukan eksplorasi lebih mendalam dengan memanfaatkan berbagai fasilitas yang tersedia.
\end{abstract}

Kata kunci : Discovery Learning, Google Classrom, Peningkatan Kemampuan Peserta Didik

\section{PENDAHULUAN}

Pendidikan menjadi landasan bagi setiap manusia untuk bisa mendapatkan pengetahuan yang semakin luas. Dengan hadirnya pendidikan yang di jalankan maka seseorang akan lebih terbuka wawasannya jauh lebih lebih luas lagi. Dalam dunia pendidikan tentunya ada beberapa pembelajaran pokok yang harus siswa pelajari di sekolah. Salah satunya adalah Bahasa Indonesia yang menjadi salah satu bagian dari pembelajaran wajib di sekolah. Ini dibuktikan dengan masuknya pembelajaran Bahasa Indonesia dalam ujian nasional yang di selenggarakan di seluruh Indonesia.

Ini berkaitan dengan bagaimana kegiatan berbahasa yang harus memiliki aliansi sekaligus pegangan yang kuat dalam bersosialisasi dalam lingkungan. Baik itu dalam lingkungan keluarga, sekolah, ataupun masyarakat luas. Bahasa sendiri berpengaruh begitu besar dalam kehidupan manusia karena dengan ini setiap manusia juga dapat mencurahkan segala isi kepalanya dengan mudah. Bahasa menjadi pembelajaran wajib yang ada kurikulum pendidikan karena memiliki peranan dalam komunikasi yang dilakukan oleh satu orang dengan yang lainnya. Seseorang yang menjalin komunikasi tentu harus menyadari bahwa bahasa yang digunakan mampu untuk orang lain terima dan juga cerna dengan baik. Hal tersebut sependapat dengan Kurniawan (2016) yang menyatakan bahwa saat seseorang menggunakan bahasa untuk berkomunikasi maka harus pertimbangkan pula apakah bahasa yang dipakai dapat laku untuk di jual yang seringkali disebut sebagai bahasa yang komunikatif.

Sebuah bahasa tentunya harus di mengerti oleh lawan bicara sehingga harus bersifat komunikatif antara satu orang dengan yang lainnya. Bahasa Indonesia sendiri pada dasarnya merupakan bahasa kesatuan rakyat Indonesia. Sehingga tidak heran apabila bahasa Indonesia sendiri menjadi salah satu mata pelajaran pokok yang wajib ada dalam kurikulum sekolah. Sebuah bahasa yang disampaikan dengan tepat tentunya tidak akan menimbulkan kericuhan ataupun permasalahan antara satu orang dengan yang lainnya. Sehingga memang penting agar setiap orang harus menggunakan prosedur kebahasaan yang baik dan juga benar.

Dalam pembelajaran bahasa Indonesia sendiri ada sebuah materi yang diajarkan pada siswa kelas XII yaitu materi mengenai teks editorial. Editorial biasanya menjadi sebuah cara untuk merespon suatu isu atau permasalahan dan memberikan tawaran solusi di akhir teks. Ini 


\section{EDUTECH : Jurnal Inovasi Pendidikan Berbantuan Teknologi Vol. 1 No. 2 Agustus 2021, e-ISSN : 2797-0140 | p-ISSN : 2797-0590}

sejalan dengan pendapat dari Kosasih dan Kurniawan (2019) yang menyatakan bahwa teks editorial sendiri merupakan sebuah kolom khusus yang ada dalam sebuah surat kabar dengan isi mengenai sebuah peristiwa yang aktual. Sehingga dapat kita tarik gambaran bahwa dalam pembelajaran ini kita berusa merespon sebuah isu ataupun berita yang sedang hangat di perbincangkan. Sekarang ini pembelajaran mengenai materi teks editorial sudah masuk dalam kurikulum 2013 yang dipelajari pada jenjang pendidikan kelas XII SMA/MA/SMK.

Pembelajaran mengenai teks editorial dapat membantu para peserta didik untuk dapat menangkap sebuah informasi ataupun berita aktual dan juga hangat tersebut dengan baik dan juga benar. Ini juga sependapat dengan pernyataan dari Pertiwi dan Dawud (2018,) yang menyatakan bahwa "Tajuk rencana adalah opini redaksi yang berisi aspirasi, pendapat, dan sikap resmi media pers terhadap persoalan potensial, fenomenal, aktual, dan atau kontroversial yang terdapat dalam masyarakat". Dalam hal ini Tajuk Rencana merupakan suatu teks atau wacana yang berisi opini, aspirasi, pendapat, dan sikap media terhadap informasi atau berita yang fenomenal, aktual, dan kontroverisal yang terjadi di lingkungan masyarakat.

Sebuah pembelajaran akan memiliki makna apabila terdapat materi yang bermakna bagi para peserta didik, dengan kata lain juga dapat dikatakan bahwa sebuah materi harus diberikan sesuai dengan karakter dari para peserta didik. Ini akan membantu hadirnya keefektifan belajar serta motivasi tinggi para peserta didik untuk mengikuti pembelajaran. Sehingga keberhasilan dalam pembelajaran akan bisa terwujud sesuai dengan harapan dari guru mata pelajaran. Pranowo (2014) menyatakan, "Materi pembelajaran Bahasa Indonesia tersedia melimpah di sekitar guru. Namun tidak setiap materi cocok diajarkan kepada pembelajar. Guru perlu melakukan seleksi atau pemilihan materi yang sesuai dengan perkembangan pikiran pembelajar". Dengan kata lain maka dapat gambarkan bahwa guru memiliki peranan penting pada keberhasilan proses belajar mengajar di sekolah. Pemilihan model pembelajaran yang tepat pada materi pembelajaran teks editorial akan berpengaruh pada keberhasilan proses belajar mengajar.

Pemilihan model yang benar - benar selektif pada sebuah materi akan membantu guru untuk lebih mudah membuat siswa lebih tertarik pada pembelajaran. Salah satu model pembelajaran yang sekarang ini banyak sekali digunakan adalah discovery learning. Pada dasarnya model pembelajaran discovery learning sendiri adalah sebuah strategi yang cenderung untuk meminta siswa melakukan sebuah observasi, eksperimen, ataupun tindakan yang ilmiah hingga kemudian dapat menyimpulkan hasil dari tindakan yang telah dilakukan (Saifuddin, 2014). Fajri (2019) juga menjelaskan bahwa model discovery learning sendiri menjadi salah satu model pembelajaran yang tepat untuk diberikan kepada para peserta didik. Peserta didik akan diajak untuk bisa menemukan sendiri apa yang mereka pelajari dan kemudian dapat mengkuonstruksikan adanya pengetahuan dengan pemahaman akan maknanya. Dalam penerapan model pembelajaran discovery learning sendiri guru hanyalah sebagai fasilitator dalam pembelajaran. Sehingga siswalah yang memegang kendali atas pembelajaran yang mereka lakukan tentunya.

Ada beberapa ciri utama dari model pembelajaran discovery learning menurut Wicaksono (2015) yaitu mengeksplorasi dan juga memecahkan masalah untuk menciptakan, menggabungkan dan menggeneralisasi pengetahuan; 2) berpusat pada siswa; 3 ) kegiatan untuk menggabungkan pengetahuan baru dan pengetahuan yang sudah ada. Puspita dkk (2016) juga menambahkan bahwa model pembelajaran Discovery Learning menekankan pada pentingnya pemahaman suatu konsep melalui keterlibatan siswa secara aktif dalam proses pembelajaran. Model pembelajaran ini menekankan pada pembentukan pengetahuan siswa dari pengalaman selama pembelajaran.

Hadirnya pandemi covid-19 telah membawa adanya perubahan dalam sistem pembelajaran yang diterapkan di sekolah. Mau tidak mau tentunya pembelajaran di sekolah tidak dapat dilakukan secara luring. Alternatif yang guru harus lakukan adalah dengan memanfaatkan berbagai media belajar online untuk peserta didik. Sehingga proses belajar mengajar masih bisa tetap berlangsung dengan baik ditengah pandemi covid-19 ini tentunya. 


\section{EDUTECH : Jurnal Inovasi Pendidikan Berbantuan Teknologi Vol. 1 No. 2 Agustus 2021, e-ISSN : 2797-0140 | p-ISSN : 2797-0590}

Ini menjadi sebuah tantangan tersendiri bagi semua elemen pendidikan yang terlibat di dalamnya. Termasuk juga dalam hal ini adalah siswa yang memegang kendali besar dalam keberhasilan pembelajaran yang mereka lakukan.

Google calsroom tentunya menjadi salah satu media online yang menjadi fasilitator tempat siswa untuk melakukan pembelajaran secara online. Pada dasarnya google sudah memberikan berbagai macam inovasi yang dapat membantu mempermudah proses pembelajaran di sekolah. Hadirnya google for education tentunya merupakan sebuah inovasi yang sudah menjadi pilihan paling populer dalam dunia pendidikan. Hadirnya beberapa layanan canggih dan membantu tentunya menjadikan ini sebagai sebuah inovasi paling apik sepanjang masa. Salah satu layanan yang google for education berikan tentunya adalah pada hadirnya layanan google classroom yang memiliki struktur sama dengan metode pembelajaran yang ada pada saat ini tentunya.

Ernawati (2018) menyatakan bahwa Google classroom sendiri sejatinya dirancang khusus untuk dapat memudahkan adanya interaksi antara guru dan juga siswa pada dunia maya. Tentunya dengan hadirnya aplikasi satu ini maka akan memberikan kesempatan besar bagi guru untuk dapat melaukan eksplorasi pada gagasan gagasan keilmuan yang dimilikinya untuk diberikan kepada siswa. Hadirnya inovas media pembelajaran ini sejatinya bertujuan untuk dapat menciptakan adanya efisiensi serta efektivitas pembelajaran yang jauh lebih menyenangkan.

Dengan adanya metode pembelajaran yang efektif di barengi dengan pemilihan alternatif media belajar yang tepat maka siswa akan jauh lebih senang dalam melakukan pembelajaran. Siswa akan dapat melakukan eksplorasi dengan lebih maksimal dalam pembelajaran yang mereka lakukan. Sehingga ini akan berpengaruh besar pada hadirnya peningkatan kemampuan yang para peserta didik miliki dalam pembelajaran. Dalam hal ini tentunya pembelajaran yang dimaksud tersebut adalah pada materi teks editorial. Hadirnya penerapan model pembelajaran discovery learning yang diberikan kepada siswa dengan berorientasi pada host melalui google classroom tentunya akan menciptakan nuansa belajar yang jauh lebih menyenangkan. Siswa akan belajar untuk dapat mengeksplorasi apa yang mereka pelajari dari materi pembelajaran yang mereka dapatkan. Tentunya ini akan secara otomatis dapat meningkatkan adanya kemampuan para peserta didik untuk memahami dan mencapai keberhasilan belajar pada materi teks editorial.

Dari penjelasan yang sudah dijelaskan diatas maka peneliti mengambil rumusan masalah mengenai bagaimana peningkatan kemampuan peserta didik dalam pembelajaran materi teks editorial dengan model discovery learning yang berorientasi hots melalui google classroom. Adapun tujuan dari penelitian ini adalah untuk dapat mengetahui peningkatan dari kemampuan para peserta didik dalam mengikuti pembelajaran materi teks editorial yang berorientasi hots melalui media belajar google classroom.

\section{METODE PENELITIAN}

Penelitian ini adalah sebuah studi pustaka dimana peneliti melakukan pencarian informasi dari berbagai sumber mulai dari buku, jurnal, hingga karya tulis ilmiah yang hadir. Data yang peneliti peroleh kemudian dijadikan menjadi sebuah satu kesatuan yang utuh dan kemudian dijadikan sebagai acuan dalam penulisan KTI ini. Sugiyono (2008) menyatakan bahwa studi literature sendiri adalah sebuah pengolahan data yang dilakukan dengan cara mencari referensi teori yang relevan dengan sebuah kasus ataupun permasalahan yang ditemukan. Studi literature sendiri merupakan sebuah cara yang digunakan untuk menyelesaikan persoalan dengan cara menelusuri sumber sumber tulisan yang pernah dibuat sebelumnya.

Dalam hal ini peneliti ingin melakukan pembahasan terkait dengan peningkatan kemampuan peserta didik dalam pembelajaran teks editorial dengan model pembelajaran discovery learning berorientasi host melalui google classroom. Dengan melakukan pencarian data secara optimal mulai dari penelusuran buku, jurnal, dan juga bahan bacaan lainnya maka 
selanjutnya peneliti kemudian menggabungkannya sebagai satu kesatuan informasi. Pemahaman yang peneliti tangkap dari berbagai literature yang didapatkan kemudian di tuangkan kedalam sebuah karya ilmiah yang berjudul "peningkatan kemampuan peserta didik dalam pembelajaran teks editorial dengan model pembelajaran discovery learning berorientasi host melalui google classroom".

\section{HASIL DAN PEMBAHASAN}

\section{Hasil}

Hasil penelitian penggunaan google classroom yang dilakukan oleh Ernawati (2018) dapat digambarkan dalam tabel berikut:

Tabel 1. Keaktifan Belajar Siswa

\begin{tabular}{lc}
\hline \multicolumn{1}{c}{ Kecenderungan keaktifan belajar siswa } & Prosentase \\
\hline Aktif & $70 \%$ \\
\hline Tidak aktif & $30 \%$ \\
\hline Total keseluruhan & $100 \%$ \\
\hline
\end{tabular}

Tabel tersebut merupakan akumulasi dari adanya pembacaan materi yang penulis dapatkan dari penelitian sebelumnya yang dilakukan oleh Ernawati (2018). Dalam pembahasannya dijelaskan bahwa google classroom memiliki peranan aktif dalam meningkatkan keaktifan belajar siswa. Siswa tidak hanya fokus pada penjelasan yang guru berikan saja, jadi dengan kata lain proses bembelajaran yang terjadi tidak monoton. Siswa bisa mendapatkan banyak sekali fasilitas belajar sebagai pendukung dari proses pembelajaran yang dilakukannya. Mulai dari adanya fasilitas seperti pembacaan jurnal, PPT, modul, dan banyak lagi yang lainnya. Sehingga para peserta didik bisa lebih maksimal dalam ikut berpartisipasi pada proses pembelajaran.

\section{Pembahasan}

Model pembelajaran yang diterapkan di sekolah menjadi sebuah landasan penting yang harus di perhatikan oleh setiap tenaga pendidik. Dalam hal ini tentunya gurulah yang memiliki peranan penting dalam proses pembelajaran siswa. Penerapan model pembelajaran discovery learning tentunya dapat secara efektif meningkatkan hasil belajar pada siswa. Ini sesuai dengan hasil penelitian yang dilakukan oleh Yuliana (2018) yang menyatakan bahwa ada pengaruh yang signifikan pada penerapan model discovery learning pada hasil belajar siswa. Tentunya dengan penerapan model pembelajaran discovery learning sendiri siswa akan bisa melakukan eksplorasi yang jauh lebih maksimal. Karena dalam hal ini tentunya guru hanya menjadi fasilitator saja, sehingga sistem pembelajaran tidaklah berpaku pada penjelasan dari google. Siswa berusaha mencari, memahami, dan menarik makna dari suatu informasi yang didapatkan. Ini menjadi sebuah poin penting pada suatu proses pembelajaran terutama pada materi teks editorial.

Dimana dalam materi pembelajaran ini memang dibutuhkan effort yang jauh lebih besar harus siswa berikan dalam pembelajaran. Dengan adanya usaha pemahaman yang jauh lebih baik maka siswa akan cenderung lebih memahami sebuah isu yang sedang hangat saat ini dengan tepat. Dimana pada materi pembelajaran teks editorial sendiri ada beberapa bagian penting yang harus siswa pahami. Tiga bagian penting tersebut diantaranya adalah bagian pengenalan isu, Argumentasi, dan Penegasan. Ketiganya akan selalu hadir beriringan pada penulisan sebuah teks editorial Neru (2014).

Pengenalan isu sendiri merupakan sebuah bagian penting yang pastinya akan ada pada awal bacaan pada teks editorial. Dalam hal ini tentunya sebuah teks editorial akan langsung mengarah pada peristiwa factual yang terjadi saat itu. Kemudian setelah itu, barulah hadir sebuah argumentasi yang menguatkan terkait dengan bagaimana kejadian factual tersebut bisa terjadi. Barulah kemudian akan ada paragraf penegasan yang biasa akan hadir dan muncul pada paragraf terakhir, dan ini juga menjadi sebuah bagian yang penting dalam teks editorial. 


\section{EDUTECH : Jurnal Inovasi Pendidikan Berbantuan Teknologi Vol. 1 No. 2 Agustus 2021, e-ISSN : 2797-0140 | p-ISSN : 2797-0590}

Mengingat pentingnya materi pembelajaran teks editorial maka harus ada model pembelajaran tepat yang siswa dan guru lakukan. Dalam hal ini tentunya penerapan model discovery learning akan membantu siswa untuk dapat menelusuri lebih dalam pemahamannya mengenai teks editorial.

Ada pula penelitian yang dilakukan oleh Cintia, dkk (2018) yang dalam hasil penelitiannya menyebutkan bahwa penggunaan model pembelajaran discovery learning akan meningkatkan kemampuan berfikir kreatif yang dimiliki oleh siswa. Hasil penelitian menunjukkan bahwa dengan penerapan model discovery learning maka siswa akan mengerahkan semua kemampuannya dalam proses pembelajaran. Ini akan mendorong siswa untuk dapat memecahkan masalah dengan kreatif dan ini dapat mendorong hadirnya pemikiran yang jauh lebih kreatif pada siswa. Selain itu dari hasil penelitiannya juga disebutkan bahwa penerapan model ini akan dapat berpengaruh aktif pada peningkatan hasil belajar siswa.

Dari hasil penelitian yang sudah di paparkan tersebut diatas maka peneliti dapat mengambil gambaran bahwa dengan penerapan model discovery learning maka siswa akan lebih banyak mengeksplorasi mengenai pembelajarannya. Sehingga dengan kata lain siswa dapat berperan aktif dalam proses belajarnya dan ini menjadi sebuah proses penting dalam pembelajaran. Dengan begitu maka tidak ada alasan bagi setiap siswa untuk tidak berpartisipasi aktif dalam pembelajaran. Ini akan menjadikan sebuah materi pembelajaran jauh lebih menyenangkan bagi siswa untuk mereka ikuti. Hadirnya pembelajaran yang menyenangka dan melibatkan siswa sepenuhnya akan menciptakan sebuah elemen baik bagi siswa. Sehingga kemampuan siswa dalam mengatasi pembelajaran akan jauh lebih optimal. Dalam kaitannya dengan pembelajaran materi teks editorial maka siswa akan lebih memahami bagian bagian penting pada teks editorial yang diberikan oleh guru. Sehingga mereka bisa mengeksplorasi dengan baik isi informasi yang ada dalam teks editorial dan bisa menangkap informasi secara maksimal.

Di samping itu juga penting untuk membahas terkait dengan efektivitas dari penggunaan media belajar google classroom. Dari beberapa hasil penelitian yang pertama dilakukan oleh Ernawati (2018) dalam hasil penelitian skripsinya menunjukkan bahwa dengan pembelajaran melalui media google classroom siswa dapat jauh lebih aktif dalam pembelajaran. Sebab, dalam hal ini siswa akan bisa memanfaatkan semua fasilitas pembelajaran yang tersedia baik dalam bentuk modul, jurnal, bahan ajar, hingga pada hadirnya ppt. Ini akan membantu siswa untuk tidak hanya bisa fokus pada satu informasi saja, namun jauh lebih mampu mengeksplorasi berbagai informasi dari berbagai sumber yang berbeda. Sehingga peningkatan kualitas belajarnya akan jauh lebih optimal nantinya.

Pada penelitian terbaru yang dilakukan oleh Nuryaningsih (2021) menunjukkan bahwa google classroom dapat meningkatkan kualitas pembelajaran siswa jauh lebih optimal dari waktu ke waktu. Sebab, siswa tidak hanya berfokus pada penjelasan yang guru berikan saja, namun ada beberapa fasilitas lainnya yang bisa siswa manfaatkan. Ini akan membantu proses pembelajaran secara lebih efektif dan hadir peningkatan hasil belajar yang jauh lebih optimal. Para peserta didik akan mendapatkan kesempatan untuk dapat lebih jauh memahami sebuah materi dengan hadirnya beragam fasilitas belajar tersedia. Apalagi dalam kaitannya dengan teks editorial yang memang membutuhkan pemahaman yang tepat untuk menarik kesimpulan dari sebuah informasi yang didapatkan dari Koran ataupun surat kabar.

Lebih jauh lagi Nuryaningsih (2021) dalam hasil penelitiannya telah berhasil menemukan pengaruh yang signifikan antara model discovery learning dengan penggunaan media google classroom dalam pembelajaran. Tentunya ada pengaruh yang signifikan antara penggunaan model discovery learning yang kemudian berkolaborasi aktif dengan penggunaan media google classroom. Hadirnya penggunaan model discovery learning yang berkolaborasi dengan pemanfaatan media google classroom yang dibantukan dengan hadirnya whatsaap telah membantu siswa untuk berperan aktif dalam pembelajaran. Ini menjadi sebuah hal yang penting dalam sistem pembelajaran. 
Secara gamblang dapat gambarkan bahwa pemanfaatan model discovery learning pada pembelajaran materi teks editorial yang berorientasi pada hots melalui google classroom telah memberikan pengaruh besar pada peningkatan kemampuan para peserta didik. Secara tidak langsung peserta didik dituntut untuk bisa meningkatkan kemampuan untuk berfikir kreatif, aktif, dan juga inovatif. Hadirnya penggabungan tiga kemampuan dasar tersebut dalam pembelajaran tentu akan dapat meningkatkan kualitas yang jauh lebih optimal nantinya. Sehingga para peserta didik akan mampu untuk mencapai keberhasilan belajar sesuai dengan target yang sudah guru tentukan.

Dalam penerapannya dimana guru hanya menjadi seorang fasilitator maka siswa harus berperan aktif untuk dapat menyelesaikan masalahnya sendiri. Teks editorial yang merupakan salah satu materi cukup rumit untuk bisa di pahami oleh siswa tanpa adanya kegigihan dalam belajar mengenai materi ini. Namun dengan adanya penggabungan kolaborasi pemanfaatan media belajar serta model belajar yang tepat maka siswa akan berperan aktif dalam pembelajaran. Hasil akhirnya tentunya berkaitan degan peningkatan kemampuan siswa yang jauh lebih maksimal baik dalam keaktifan, hasil belajar, dan juga kemampuan untuk berpikir kreatif.

Dengan kolaborasi yang diterapkan secara tepat maka siswa akan mempu untuk dapat melakukan observasi terkait dengan materi yang dipelajari. Ini akan membuat tingkat kemampuan peserta didik untuk menganalisa suatu masalah dengan lebih mendalam akan lebih mudah untuk mereka dapatkan. Ini menjadi tujuan dari pembelajaran yang memang harus siswa dapatkan pada akhir pembelajaran. Guru harus bisa menerapkan langkah langkah tepat dengan pemberian model belajar discovery learning yang kemudian di orientasikan pada hots melalui google classroom tentunya

\section{KESIMPULAN}

Dari pembahasan yang sudah diuraikan diatas maka peneliti dapat menarik kesimpulan bahwa peningkatan kemampuan peserta didik terlihat begitu signifikan. Adanya pemanfaatan model belajar menggunakan model discovery learning yang berorientasi hots melalui google classroom akan secara signifikan meningkatkan kualitas belajar peserta didik. Hadirnya peningkatan kualitas belajar yang para peserta didik dapatkan akan membuat mereka bisa secara aktif meningkatkan kemampuan yang dimiliki. Baik itu kemampuan eksplorasi, berpikir kreatif, dan juga penganalisaan terhadap suatu masalah. Sehingga hasil akhirnya akan terlihat pada hasil belajar yang para peserta didik tunjukkan di akhir pertemuan nantinya.

\section{DAFTAR PUSTAKA}

Cintia, N. I. dkk. (2018). Penerapan Model Pembelajaran Discovery Learning Untuk Meningkatkan Kemampuan Berpikir Kreatif Dan Hasil Belajar Siswa. Jurnal Perspektif Ilmu Pendidikan, Vol. 32 No. 1

Dawud \& Pertiwi, L. B. (2018). Argumentasi Dalam Teks Tajuk Rencana Harian Suara Merdeka. Jurnal Kajian Bahasa, Sastra Indonesia, dan Pembelajarannya, Volume 2 Nomor 1, 2018.

Ernawati. (2018). Pengaruh Penggunaan Aplikasi Google Classroom Terhadap Kualitas Pembelajaran dan Hasil Belajar Siswa Pada Mata Pelajaran Ekonomi Kelas XII di MAN 1 Kota Tengerang Selatan. Skripsi. Fakultas Ilmu Tarbiyah dan Keguruan Universitas Islam Negeri Syarif Hidayatullah Jakarta.

Fajri, Zaenol. (2019). Model Pembelajaran Discovery Learning Dalam Meningkatkan Prestasi Belajar Siswa SD. Universitas Nurul Jadid, Paiton. Jurnal IKA Vol. 7 No. 2

Kurniawan, Albert. (2016). Adaptasi Bauran Komunikasi Pemasaran pada Pedagang Pasar Klewer Surakarta. http://digilib.machung.ac.id/index.php?p=show_detail\&id=1986 diakses pada 5 Desember 2017, 18:39 WIB

Kosasih, E. dan Kurniawan, Endang.(2019). Jenis-Jenis Teks. Bandung: Yrama Widya.

Neru, K. S. (2013). Modul Teks Editorial. Bahan Ajar Siswa Kelas XII 
Nuryaningsih, W. D. (2021). Penerapan Model Discovery Learning Berkolaborasi Google Classroom dan WhatsApp Group untuk Meningkatkan Kompetensi Siswa dalam Menulis Teks Eksplanasi. Jurnal Penelitian dan Pengembangan Pendidikan Vol. 8, No. 2

Yuliana, Nabila. (2018). Penggunaan Model Pembelajaran Discovery Learning Dalam Peningkatan Hasil Belajar Siswa Di Sekolah Dasar. Jurnal Ilmiah Pendidikan Dan Pembelajaran. Vol. 2 No. 1 P-ISSN : 1858-4543 E-ISSN : 2615-6091

Pranowo. (2014). Teori Belajar Bahasa Untuk Guru Dan Mahasiswa Jurusan Bahasa. Yogjakarta: Pustaka Pelajar.

Puspita Dewi., Rizky, Agung Nugroho., Catur Saputro., dan Ashadi. (2016). Penerapan Model Pembelajaran Discovery Learning Untuk Meningkatkan Minat Dan Prestasi Belajar Siswa Pada Materi Kelarutan Dan Hasil Kali Kelarutan Kelas XI Mia 3 Semester Genap SMA N 1 Teras Tahun Pelajaran 2015/2016. Jurnal Pendidikan Kimia, Universitas Sebelas Maret. Volume 5, No 4, Hal.115

Saifuddin. (2014). Pengelolaan Pembelajaran Teoretis Dan Praktis. Yogyakarta: Deepublish. Sugiyono. (2008). Memahami Penelitian Kualitatif. Bandung: Penerbit Alfabeta.

Wicaksono, Dkk. (2015). Teori Pembelajaran Bahasa (Suatu Catatan Singkat). Yogyakarta: Garudhawaca. 